DIGITALCOMMONS

@WAYNESTATE -
Michigan Journal of Counseling:

Research, Theory and Practice

Volume 34 | Issue 1

Article 3

$5-1-2007$

\title{
Awareness of Requirement to Teach About Penalties of Underage Sex in Michigan Schools
}

Sharie Reznich

Central Michigan University

Follow this and additional works at: https://digitalcommons.wayne.edu/mijoc

\section{Recommended Citation}

Reznich, S. (2007). Awareness of Requirement to Teach About Penalties of Underage Sex in Michigan Schools, Dimensions of Counseling, 34(1), 8-13. doi:10.22237/mijoc/1177977720

This Article is brought to you for free and open access by the Open Access Journals at DigitalCommons@WayneState. It has been accepted for inclusion in Michigan Journal of Counseling: Research, Theory and Practice by an authorized editor of DigitalCommons@WayneState. 


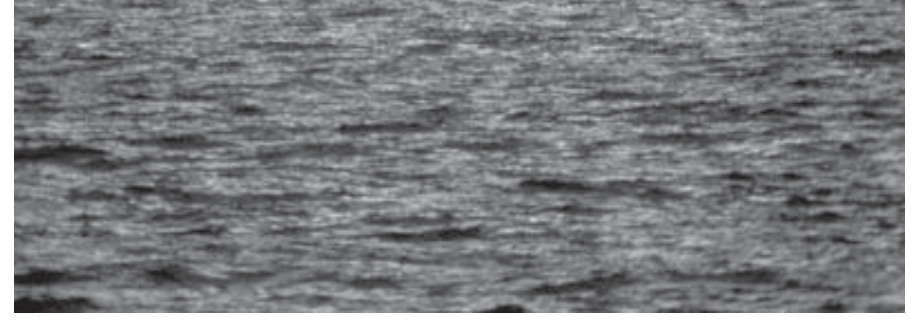

\section{Awareness of Requirement to Teach About Penalties of Underage Sex in Michigan Schools}

\section{Sharie Reznich}

Central Michigan University
In October of 2003, an amendment to Section 166 a ( $\beta 388.1766 a)$ of the State School Aid Act, regarding sex education, went into effect. It states:

That the sex education instruction includes information clearly informing pupils that having sex or sexual contact with an individual under the age of 16 is a crime punishable by imprisonment, and that 1 of the other results of being convicted of this crime is to be listed on the sex offender registry on the internet for at least 25 years. ( $p .3$ )

Questions surround the implications of this law. Are schools even aware of the law's existence? How has this change been communicated to schools? What are the expectations of how the material is presented? What are the most effective ways to communicate this type of information to students? Does this law have an effect on confidentiality issues? The researcher surveyed 200 Michigan school counselors to gather answers to some of these questions as one step in an effort to improve the health and well-being of Michigan students.

ex education in schools is often an area of controversy. Families, schools, communities and the legislature often disagree on what is the best for children and adolescents. In the 1970s changes were made to Michigan state law to provide for the teaching of sex education and family planning in public schools (T. Bergstrom, personal communication, March 29, 2004). In the 1980s with the increase in Human Immunodeficiency Virus (HIV) and other sexually transmitted infections (STIs), more legal requirements regarding the teaching of health and sex 
education were implemented. The State of Michigan's State Board of Education published a policy in September 2003 that indicated the importance (and requirement) of schools to work with families and communities for providing sexuality education programs that will influence students to make healthy choices throughout their lives. In October of 2003, an amendment to Section 166a (B388.1766a) of the State School Aid Act, regarding sex education, went into effect. It states:

That the sex education instruction includes information clearly informing pupils that having sex or sexual contact with an individual under the age of 16 is a crime punishable by imprisonment, and that one of the other results of being convicted of this crime is to be listed on the sex offender registry on the internet for at least 25 years. (p.3)

Questions surround the implications of this law. Are schools even aware of the law's existence? How has this change been communicated to schools? What are the expectations of how the material is presented? What are the most effective ways to communicate this type of information to students? Does this law have an effect on confidentiality issues? This study surveyed 200 Michigan school counselors to gather answers to some of these questions as one step in an effort to improve the health and well-being of Michigan students.

What is sex education? The Sexuality Information and Education Council of the United States (SIECUS) defines sexuality education as "a lifelong process of acquiring information and forming attitudes, beliefs and values" $(2001, \partial 2)$. The same article reports on the aspects of sex education in the home, at school, and continues with information about government's role in sex education (SIECUS).

"The federal government's involvement in sex education has primarily been to provide funding for education programs" reports the Kaiser Family Foundation (2002, p.1). Since 1988 the Centers for Disease Control and Prevention (CDC) has included funding for HIV education. All states except Ohio and Utah receive this HIV education funding (Kaiser Family Foundation). The federal government has other sex education funding programs, but most education policy is regulated by states individually.
Not all states require sex education. Some states, including Michigan, require HIV / STI instruction but not sex education (Alan Guttmacher Institute, 2004).

In states that offer sex education, there are significant differences between states regarding what subject matter is taught. In Michigan, as in some other states, if sex education is taught, then there are specific requirements regarding the curriculum that is taught (Kaiser Family Foundation, 2002). No record was found of any state other than Michigan having policies concerning the teaching of the penalties of underage sex.

In regard to local school district policy, superintendents cite state directives as the most important factor in determining the sex education

curriculum (Kaiser Family Foundation, 2002). Developing sex education curriculum for a district usually involves a representative group of people, including parents, teachers, local health professionals, counselors, and other interested community members. Research has shown that there are some common characteristics for effective sex education programs (Kirby, 2000), but often each of the parties involved has his/her own ideas.

The results of the 2003 Michigan Youth Risk Behavior Survey (Michigan Department of Education, 2004) illustrate that a large population $(46 \%)$ of high school students are sexually active; therefore there are students who are potentially in violation of the Criminal Sexual Conduct Statutes (1931). As reported at the Ramifications of Underage Sex program (Clulo, Allen, Donker, \& Duke, 2004), and as discovered through conversations with area school counselors (personal communications, JanuaryApril 2004), many high school students are unaware of many of the laws about underage sexual behavior. This may be one reason the Michigan legislature enacted the law to include informing students of the consequences of underage sex as part of their sex education curriculum.

\section{Research Questions}

1. Do students share information with their school counselors about their sexual activity?

2. Do school districts have policies regarding confidentiality and when to report and/or call parents about underage sexual activity? 
3. Are school counselors aware of the requirement to teach about the penalties of underage sex?

4. Is there school district policy for communication about new legal requirements for schools?

5. Who is responsible for teaching about the penalties of underage sex in various districts?

\section{Method}

Questionnaires were sent to 200 Michigan school counselors. The counselors were selected from the Michigan Counseling Association Directory. The

names chosen were those listed as secondary school counselors. Participation was voluntary and anonymous. The questionnaire consisted of five questions with space for comments. A stamped pre-addressed envelope was included for ease of return to the researcher. A sample of the questionnaire is in the Appendix.

\section{Results}

115 completed surveys were returned for a response rate of $59 \%$. Six surveys were returned undeliverable because of incorrect addresses.

Most counselors (84\%) surveyed said that students do share information about their sexual activity. There were varied comments to qualify their responses, such as "sometimes," "occasionally," or "if they are active and possibly pregnant." In regards to school district policy about confidentiality and reporting underage sexual activity to parents, results were mixed. $36 \%$ of counselors said their school district had a policy, 37\% said they did not, and $27 \%$ reported they did not know if there was one.

The responses to the question on the survey that asked about the counselor's awareness of the state requirement
Table 1

Survey Responses

\begin{tabular}{lccc}
\hline Question & Yes & No & $\begin{array}{c}\text { Other/ } \\
\text { Don't Know }\end{array}$ \\
\hline $\begin{array}{l}\text { Do students share information with you } \\
\text { about their sexual activity? }\end{array}$ & $84 \%$ & $10 \%$ & $5 \%$ \\
\hline $\begin{array}{l}\text { Does your school district have a policy regarding } \\
\text { confidentiality and when to report and/or call } \\
\text { parents about underage sexual activity? }\end{array}$ & $36 \%$ & $37 \%$ & $27 \%$ \\
\hline $\begin{array}{l}\text { Are you (or were you, before receiving this survey) } \\
\text { aware of the State of Michigan's requirement } \\
\text { for schools to teach about the penalties for } \\
\text { underage sex? }\end{array}$ & & & \\
\hline $\begin{array}{l}\text { Does your school district have a policy for } \\
\text { communication about new legal requirements } \\
\text { (of any kind) for schools? }\end{array}$ & $24 \%$ & $24 \%$ & $50 \%$ \\
\hline
\end{tabular}

for schools to teach about the penalties for underage sex were split; $60 \%$ of the counselors surveyed were aware of the law and $40 \%$ were not. The issue of knowledge of district policy regarding communication about legal requirements received 25\% Affirmative, 25\% Negative and $50 \%$ Don't Know answers.

The final question on the survey asked who was responsible for teaching about the penalties for underage sex. The counselors often chose more than one of the options presented and many offered comments. The responses to this question are shown in Table 2. Some of the comments were: "An outside agency comes inthrough science class," "I assume," "probably discussed in Health class," and "This year with the new law, sex ed is not being taught at all until further notice."

\section{Table 2}

\section{Person Responsible for Teaching Penalties of Underage Sex}

\begin{tabular}{lccccccccc}
\hline Question & $\begin{array}{c}\text { Health } \\
\text { Teacher }\end{array}$ & $\begin{array}{c}\text { Science } \\
\text { Teacher }\end{array}$ & $\begin{array}{c}\text { Gym } \\
\text { Teacher }\end{array}$ & Counselor & Administrator & $\begin{array}{c}\text { Non-school } \\
\text { employee }\end{array}$ & Nurse & Don't Know & None \\
\hline $\begin{array}{l}\text { Who in your district is responsible } \\
\text { for teaching about the penalties } \\
\text { of underage sex? }\end{array}$ & $68 \%$ & $4 \%$ & $10 \%$ & $10 \%$ & $7 \%$ & $5 \%$ & $1 \%$ & $17 \%$ & $2 \%$ \\
\hline
\end{tabular}

Note: Respondents sometimes chose more than one person when answering this question. 


\section{Discussion}

The answer to the central question of this whole study is that most $(60 \%)$ school counselors are aware of the law that requires schools to teach about the penalties of underage sex. That statistic, though, means that $40 \%$ of Michigan school counselors are unaware of the law. The law has been in effect since October 2003.

Michigan State Senator Mike Goschka wrote that "To my knowledge, the manner in which school districts learn of changes or proposed changes to legislation that will directly affect them is through their network of lobbyists" (personal communication, March 19, 2005). He indicated he wasn't sure of the exact channels, whether it would be through the Superintendents' offices or through ISD/ RESDs. Perhaps this issue of communication about new legal requirements is one for administrators, but this particular instance illustrates a reason why the communication should go beyond the administrative staff and those responsible for teaching the specific topic. Counselors are in unique positions in that students often trust them enough to talk about their sexual activity. Even if not legally bound to report underage sexual activity, a counselor would be in an effective position to teach students about the law if they themselves were aware of it.

To answer the question about the most effective ways to communicate this information to students would entail another study, but several ideas were submitted with the survey results. Most often cited was that the legal ramifications of underage sex were taught by health teachers in class. They were offered at various grade levels, but other health class curriculum details were not given. Several counselors said that their districts brought in outside speakers. One was from a women's aid shelter and spoke of the law in the context of sexual harassment and relationships. That program was presented to sixth, seventh, and eighth grade health classes. Some districts use local law enforcement officials to give lectures to various grade levels, some annually. In Oakland County, a video was produced and distributed to schools.

The most comprehensive program mentioned by counselors returning the surveys appears to be the one developed by the Midland County Court System, Midland County Prosecutor and Midland Public Schools. Their PowerPoint presentation begins:

This program is designed to provide an explanation of the law that defines criminal sexual conduct, or "CSC," in our state. It reflects the belief of both law enforcement and the judiciary that, by understanding the law, Michigan youth can promote respect for self and others, avoid becoming victims, or unwitting perpetrators, of CSC offenses, and help stem the tide of misinformation about these offenses which often exists among their peers. (April, 2004)

In Midland, the presentation by a panel of local professionals is given to school staff and parents first, and then shown to all eighth graders in the district. Linda Weiss, Deputy Court Administrator and Attorney Referee, $42^{\text {nd }}$ Circuit Court in Midland is a resource for anyone interested in coordinating a program for schools in other areas of the state.

One of the easiest suggestions to implement was to include the law in student handbooks and publish it in district newsletters. Although the law indicates that it needs to be taught or be included with sex education instruction, having it printed and available in various formats would be an additional communication tool.

Does the law have an effect on confidentiality issues? The law per se shouldn't affect confidentiality, because it is only about the requirement of schools to teach about the consequences of underage sex. The increased awareness and communication about sexual activity and the law by counselors, school staff, students, and parents may bring up confidentiality concerns. The counselors' answers to the survey question regarding confidentiality and school policy indicates an area many counselors expressed apprehension about. They responded that $27 \%$ didn't know if there was district policy and 37\% replied that there was not district policy regarding confidentiality and when to report and/or call parents about underage sexual activity.

One survey respondent replied, "We are required to inform parents-I ask the student to do it to take responsibility." A few other counselors gave similar comments, illustrating that some districts do have policy that directs counselors to break confidentiality regarding underage sexual activity. Another school district's policy states that information shared with a counselor does not need to be shared with anyone including parents unless the student's health or well-being is in danger. District policy can help make this very gray area a little clearer.

From a legal standpoint, Assistant Prosecutor J. D. Brooks of Midland said in most situations, consensual sex 
between teenagers does not need to be reported (April, 2004). It is not a violation of the Child Protection Law of which counselors are mandatory reporters. It is important to know the Criminal Sexual Conduct Laws and be able to talk with students about them and the possible consequences of violating them. As reported by Mitchell and Rogers (2003), "if school counselors find themselves knowledgeable of situations where age discrepancies between mutually consenting sexual partners are questionable, they should call their local department of child services or prosecuting attorney and present a hypothetical case describing the circumstances" (p.336).

The question of confidentiality with parents isn't so clear. Again, if there is district policy, a counselor should refer to it. The American School Counselor Association's (ASCA) position statement on the professional school counselor and parental consent states, "It is the responsibility of the professional school counselor to reach an agreement with the student concerning the information to be shared with the parent unless there is clear and imminent danger to the student or others as specified in ASCA's Ethical Standards for School Counselors" (2004, 24). This position could be argued legally, because in most cases, the right to consent belongs to the parent. Behnke and Warner (2002) refer to Ethics Code to reach for the answers in light of the apparent conflict between the law and "good clinical treatment." When deciding what is in the best interest of the student, it is most important to know the "mandatory reporting requirements and to be liberal in the use of consultation" (p.2).

In all instances, the need for informed consent or clear explanations of the limits of confidentiality can not be overemphasized. Communication of these should be done routinely with students during initial sessions and publicized in student handbooks and other materials that are distributed to parents. A sign posted in the school counselor's office could be referred to on a regular basis.

\section{Summary}

The health and well-being of students is a counselor's top priority. Sexual activity impacts a teenager's health and well-being. A school counselor is in a unique position in that students often trust them enough to confide in them about their sexual activity; therefore, a counselor needs to be aware of any legal and ethical concerns they may encounter in counseling sexually active students. The law about teaching the penalties of underage sex is just one example of why it is important to keep abreast of new laws and district policies. Involvement with administrators and other school staff in the development of a Sexuality/Health Education curriculum would be valuable for a counselor and the students that he or she serves. Continuing education and consultation with colleagues and supervisors will keep a counselor informed and prepared to meet the special needs of today's young people.

\section{References}

Allen Guttmacher Institute. (2004, April). Sex and STD/HIV education (State Policies in Brief). New York, NY.

American School Counselor Association. (2004). Position Statement: The Professional School Counselor and Parental Consent. Retrieved March 21, 2005, from http: / / schoolcounselor.org/ content.asp? contentid $=213$

Behnke, S. H. \& Warner, E. (2002). Confidentiality in the treatment of adolescents. Retrieved March 23, 2004, from http: / / smph.psych.ucla.edu/qf/confid_qt/ Confidentiality_in_treatment_adolescents.pdf

Clulo, P., Allen, D. S., Donker, N. W., \& Duke, D. (2004, April). Legal ramifications of underage sexual activity. Presented at the Ramifications of Underage Sexual Activity seminar sponsored by Partnership for Youth, Midland, Michigan.

Criminal Sexual Conduct Statutes, Michigan Penal Code Act 328 of 1931. MI Compiled Laws

(2003). Retrieved March 23, 2004, from http:/ / www.emc.cmich.edu/ $\mathrm{HIV} /$ pdf/ CSC1-4wdefinitions.pdf

Educational Materials Center. (2004). Sexuality and HIV/STD prevention education. Retrieved March 23, 2004, fromhttp:// www.emc.cmich.edu/HIV/milaw1.htm

Educational Materials Center. (2004). The law in Michigan. Retrieved March 23, 2004, from http:/ / www.emc.cmich.edu/HIV/ milaw1.htm

Kaiser Family Foundation. (2002, October). Sex education in the U.S.: Policy and politics (Issue Update No.3224-02). Menlo Park, CA.

Kirby, D. (2000) What does the research say about sexuality education? Educational Leadership, 58 (2), 72-76.

Michigan Department of Education. (2004). 2003 Michigan youth risk behavior survey. Retrieved March 23, 2004, from http:/ / www.michigan.gov/documents / 2003_MI_YRBS_Chart_84900_7.pdf

Michigan School Code Regarding Sex Education, HIV Education, Health Education and Physical Education. State School Aid Act of 1979, Section 166a (B388.1766a) (2003).

Mitchell, C. W. \& Rogers, R. E. (2003). Rape, Statutory Rape, and Child Abuse:

Legal Distinctions and Counselor Duties. Retrieved March 13, 2005, from www.schoolcounselor.org/files / 6-5-332\%20Mitchell.pdf

Sexuality Information and Education Council of the United States. (2001). Issues and answers: Facts sheet on sexuality education.

Retrieved April 11, 2004, from http:/ / www.siecus.org/pubs / fact0007.html

State of Michigan State Board of Education. (2003). Policy to promote health and prevent disease and pregnancy. Retrieved March 23, 2004, from http: / / www.emc.cmich.edu/HIV/pdf/Policy77377-7.pdf 


\section{Appendix}

\section{Survey for Michigan School Counselors}

1. Do students share information with you about their sexual activity? Yes No

Comments

2. Does your school district have a policy regarding confidentiality and when to report and/or call parents about underage sexual activity? Yes No Don't Know

Comments

3. Are you (or were you, before receiving this survey) aware of the State of Michigan's requirement for schools to teach about the penalties for underage sex? Yes No

Comments

4. Does your school district have a policy for communication about new legal requirements (of any kind) for schools? Yes No Don't Know

Comments

5. Who in your district is responsible for teaching about the penalties of underage sex?

Health teacher Science teacher Gym teacher Counselor

Administrator Non-school employee Don't Know

Comments

Any comments or details about policies or programs that you feel might benefit other districts would be welcome:

Please return in the enclosed stamped addressed envelope

(by ). Thank You! 